ELORE (ISSN 1456-3010), vol. 18 - 1/2011.

Julkaisija: Suomen Kansantietouden Tutkijain Seura ry.

[http://www.elore.fi/arkisto/1_11/ajank_koski.pdf]

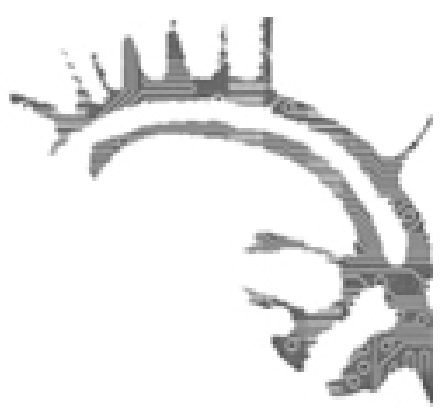

\title{
Ajankohtaista
}

\section{KUOLEMA ELÄVIEN NAAPURINA}

\section{$\underline{\text { Kaarina Koski }}$}

Lectio praecursoria Helsingin yliopistossa 5.3.2011

Ihmiskunnan kuolemisen historiassa nykyaikainen länsimainen kulttuuri on täysin poikkeuksellinen. Vaikka väestön kuolleisuus on edelleen sata prosenttia, kuolemaa on lääketieteen avulla onnistuttu lykkäämään ja hidastamaan. Valtaosa ihmisistä kuolee vasta hyvin iäkkäinä. He ovat jo lopettaneet työuransa, monet ovat myös vetäytyneet aktiivisesta roolistaan yhteiskunnan ja sukunsa jäseninä. Tietoisuus omasta tuhoutumisesta kuolemassa ja läheisten menettämisestä on edelleen katkeraa nieltävää. Mutta hyväksymistä helpottaa se, jos elämäntyö on saatu päätökseen ja elämänkaari täydeksi. Sen sijaan järkytymme edelleen väkivaltaisista ja tapaturmaisista kuolemista, nuorten sekä erityisesti lasten kuolemista.

Vielä sata vuotta sitten - ja siitä taaksepäin loputtomiin - huomattavasti suurempi osa kuolemista oli näitä järkyttäviä kuolemia. Kaikenikäisiä kuoli tauteihin ja tapaturmaisiin vammoihin, joita ei pystytty hoitamaan. Kuolema niitti lapsia ja nuoria sekä sellaisia naisia ja miehiä, joista eloonjääneet olivat taloudellisesti riippuvaisia. Niukkuudessa eläneille varhaiskantaisille yhteisöille kuolema oli joskus järjetöntä elinvoiman tuhlausta. Vaikka kuolema oli osa luonnonjärjestystä, se edusti kaikkea sitä, mitä vastaan ihmisyhteisöt taistelivat luonnon ja kulttuurin välisessä kamppailussa: tuhoa ja mätänemistä, ennustamatonta ja hallitsematonta kaaosta, pimeyttä ja kylmyyttä. Uskonnoissa, joiden mukaan ihmisistä tuli kuolevaisia tottelemattomuutensa vuoksikuten syntiinlankeemuksen kautta - kuolema edusti myös moraalittomuutta ja syntiä. 
Kaarina Koski: Kuolema elävien naapurina

\section{HYvä JA PAHA KUOLEMA}

Kuolema oli siis paha ja pelottava, mutta koska siitä ei voitu päästä eroon, siitä rakennettiin kuvaa myös siedettävänä ja hyvänä. Useimmat uskonnot vakuuttavat, että elämä jatkuu kuoleman jälkeenkin; vain toisessa muodossa. Yksilön kannalta kuoleman voi selittää portiksi parempaan maailmaan. Mielikuvat ikuisesta elämästä voivat olla paratiisimaisia ja ihania. Yhteisön kannalta taas on tärkeää, että turvallinen järjestys pysyy hallinnassa kuoleman väliintulosta huolimatta ja yhteisö säilyy elinvoimaisena ja toimintakykyisenä. Kaikissa kulttuureissa kuolemaan ja hautaamiseen liittyy rituaaleja, joiden avulla kuolemisen ja menetyksen prosessia otetaan hallintaan. Oikein suoritetut rituaalit muuttavat kuoleman oikein tapahtuneeksi. Taustalla on ajatus, että näin käsiteltynä kuolema johtaa sekä yhteisön että yksilön kannalta suotuisiin tuloksiin. Rituaalien saattelemana sielu saa rauhan tai pääsee uuteen elämään. Menetetty elinvoima palaa yhteisön käyttöön hedelmällisyytenä. Vainajan muistosta tulee esikuvallinen. Yhteisön ihanteisiin sovitettua kuolemaa on voitu pitää hyvänä, jopa kauniina.

Aina niin ei kuitenkaan käy. Kuolemia, jotka ovat yhteisön katsannossa erityisen järkyttäviä tai moraalittomia, ei voida rituaalisestikaan kääntää hyviksi. Surmatut kummittelevat. Pahantekijät harhailevat saamatta rauhaa. Paratiisinkin kääntöpuolelta löytyvät kadotus ja helvetti. Uskomusjärjestelmät ovat pyrkineet lieventämään kuoleman herättämää pelkoa, mutta ne ovat myös hyödyntäneet ja jopa lietsoneet sitä. Kansaa on pidetty kurissa ja nuhteessa mielikuvilla sekä kuolemasta itsestään että vainajista. Kuolemaan on ladattu palkkion tai rangaistuksen odotus.

Vainajien taas on uhattu kostavan tai rankaisevan jo tässä elämässä. Suomalaisten muinaiseen vainajakulttiin kuului ajatus vainajista hautausmaan asukkaina, joita oli syytä muistaa ja lahjoa. Elävät olivat esi-isilleen kiitollisuudenvelassa sekä elämästään että perimistään maista. Vainajien suuttumuksesta olisi tullut kohtalokkaita seurauksia, sillä heidän vallassaan olivat sekä terveys että elinkeinojen menestyminen. Tällainen vainajakultti kuului suomalaiseen kulttuuriin ennen kristinuskon tuloa ja osittain sen jälkeenkin.

Keskiajalla katolinen kirkko asettui välittäjäksi yhteisön elävien ja kuolleiden jäsenten välillä. Siunaustensa avulla se suojeli seurakuntaa pahoilta voimilta. Kirkon mukaan sielut eivät tarvinneet kiirastulessa lihaa ja leipää vaan rukouksia ja messuja. Kirkko otti siis vastaan kuolleille tarkoitetut aineelliset lahjat ja muunsi ne hengelliseksi huolenpidoksi. Tätä jatkui melkein puoli vuosituhatta, kunnes uskonpuhdistus muutti kirkon virallisen kannan. Luterilainen kirkko ei tunnustanut kiirastulta eikä sallinut vainajakultin kristillistenkään muotojen jatkua. Ihmisten ei tullut olla elämästään kiitollisia kuolleille vaan Jumalalle. Vainajilla ei kirkon mukaan ollut mitään asiaa maan päälle eikä valtaa sen asioihin, eivätkä ne myöskään voineet palata elävien keskuuteen haamuina. Kaikki sellaiseen viittaavat näyt olivat vain demonien eksytystä. Kontaktit tuonpuoleiseen oli tulkittava liitoksi paholaisen kanssa. 


\section{Kaarina Koski: Kuolema elävien naapurina}

\section{VAINAJILLA ON TOIMINTAKYKYÄ JA VOIMAA}

Miten kansa otti vastaan nämä näkemykset? Kirkko onnistui kyllä katkaisemaan kiinteän sukusiteen elävien ja kuolleiden välillä. Elävien suhde vainajien yhteisöön oli ennen ollut kahtalainen. Nyt vainajat muuttuivat vieraammiksi ja vaarallisemmiksi. Mutta käsitystä vainajien kulkemisesta kuolemansa jälkeen olisi ollut vaikea kitkeä kokonaan. Kaikissa kulttuureissa osalla ihmisistä on omia kokemuksia vainajien kohtaamisesta. Ne liittyvät erityisesti yllättäviin kuolemiin. Tiede selittää niitä mielen rakenteella ja suruprosessiin kuuluvalla stressillä, joka voi olla voimakasta ensimmäisinä menetyksen jälkeisinä viikkoina. Suomessa myös uskomusperinne vahvisti, että vainajat ovat aktiivisimmillaan ensimmäisinä viikkoina kuolemansa jälkeen.

Eurooppalaisen kansanuskon mukaan vainajilla oli toimintakykyä niin kauan kuin luissa oli vielä lihaa. Fyysisen kuolemisen prosessi jatkui siis vielä hautaamisen jälkeen. Sanoivatpa papit mitä tahansa, kirkkomaalla makasi osittain toimintakykyisiä vainajia. Tämä oli yksi hyvä syy karttaa kirkkomaita. Katolisella ajalla kirkkomaan vihkiminen oli tehnyt siitä erityistä pyhää aluetta. Kansanuskossa sen erityisyys kumpuaa myös vainajien voimasta. Hautausmaan multa, kuolleiden luut ja hautaristien osatkin sisälsivät kuoleman voimaa, kalmaa, joka oli vaarallista ja tartuttavaa. Kirkko ja esivalta kielsivät ankarasti käyttämästä näitä kirkon ja vainajien voimia taikuudessa. Sekä kansanrunouslähteet että tuomiopöytäkirjat kuitenkin osoittavat, että taikoja harjoitettiin. Jyrkkä kielto luultavasti vain lisäsi niiden mainetta. Koska ne olivat niin ankarasti kiellettyjä ja vaarallisia, niiden oli oltava myös tehokkaita. Ruumiiden silpomisesta taikatarpeisiin on langetettu tuomioita vielä 1900-luvulla.

\section{TÄMÄ JA TOINEN TODELLISUUS}

Väitöskirjatutkimukseni ei tarkastele itse kuolemaa vaan kahden erilaisen yhteisön rinnakkaineloa: elävien ja kuolleiden. Aineistonani on ollut noin 2700 arkistoyksikköä kertomuksia ja muita tiedonantoja 1800-luvun lopulta 1960-luvulle. Sisällöltään ne vastaavat 1800-luvun uskomusperinnettä. Suuri osa aineistosta on uskomustarinoita. Tarinoissa varomattomat kontaktit vainajiin ja ruumiisiin aiheuttavat vaaratilanteita ja uhkaavat koko yhteisön järjestystä. Kansanuskossa kuolema ei ole vain elämän päätteeksi koettava kohtalo, vaan se on elämän vastapari, joka on jatkuvasti läsnä. Kuoleman läsnäolo oli konkreettisempaa kuin osaamme kuvitella. Ruumiiden valmistelu hautaan oli omaisten vastuulla, ja ahtailla kirkkomailla jouduttiin siirtelemään melko tuoreitakin maallisia jäännöksiä. Kaiken, mikä oli ollut ruumiin kanssa tekemisissä - ruumiin pesuvedestä hautausmaan multaan - koettiin olevan tartuttavaa. Tartunta merkitsi yhteyttä toiseen, näkymättömään todellisuuteen, joka oli henkien ja vainajien hallitsemaa. Sieltä kuolemaa edustavat olennot saattoivat aika ajoin tunkeutua myös arkitodellisuuteen.

Uskomusperinteessä kirkonväellä tarkoitetaan näitä kuolemaa edustavia olentoja. Väkeä on nimitetty myös manalaisiksi, männingäisiksi, hittusiksi, kööpeleiksi, ruumiin- 


\section{Kaarina Koski: Kuolema elävien naapurina}

haltijoiksi ja monilla muilla nimillä. Kirkonväki kuvataan joskus vainajien hengiksi, joskus kalmanhajuiseksi, sumunkaltaiseksi parveksi, joskus taas näkymättömäksi voimaksi, josta käytettiin myös nimitystä kalma. Tavalliset ihmiset eivät yleensä nähneet kirkonväkeä. Erityiset näkijät näkivät sitä kuoleman enteenä tai tunsivat kalmanhajua kuolinsanoman edellä. Kuolema ja hautaamattoman ruumiin sijainti kotipiirissä merkitsivät epätasapainoa elävien ja kuolleiden välillä. Sen vuoksi kirkonväkeä oli liikkeellä. Se saapui noutamaan kuolijaa ja parveili ruumisriihissä ja hautajaissaatoissa.

Tämä on perinnettä, joka havainnoi kuolemantapauksia välimatkan päästä. Väki ei kuulunut niihin lohdullisiin mielikuviin, joita ihmiset halusivat kokea oman tai läheisensä kuolinvuoteen äärellä. Päinvastoin: Kirkonväki edusti kaaosta ja kuoleman hallitsemattomuutta. Sellaisena se liitettiin erityisesti surmiin, itsemurhiin ja syntisiin kuolemiin. Mitä rumempaa ja mustempaa väki oli, sitä karumpaa viestiä se kertoi kuolijan sielusta.

\section{JÄRJESTYKSEN JA KAAOKSEN RAJOILLA}

Uskomusperinteessä kummittelu on merkki siitä, että asiat eivät ole järjestyksessä, ja samalla se on kehotus ja pyrkimys asioiden korjaamiseen. Kirkonväki piti järjestystä elävien ja kuolleiden välillä. Kertomuksissa se haki pois ihmisten hautausmaalta ottamia luita tai esineitä sekä hääti - joskus suorastaan heitti - hautausmaalta asiattomasti käyttäytyvät ihmiset. Kalmasairaus uhkasi kaikkia niitä, jotka olivat varomattomia kuoleman äärellä. Kirkonväkeä pelättiin, sen kynsissä saattoi menettää henkensä.

Kirkonväkeä liikutettiin myös tarkoituksella. Juuri siihen tähtäsivät hautausmailla tehdyt taiat. Tietäjät hankkivat vainajilta tai väeltä tietoa, jota he käyttivät sairauksien parantamisessa ja varkauksien selvittämisessä sekä lähettivät sitä vihamiestensä kiusaksi. Yksinkertaisempiin kalmataikoihin saattoivat turvautua vaikkapa toisiinsa suuttuneet naapurukset. Hautausmaalta haettiin multaa tai luita ja kylvettiin niitä naapurin pihaan tai piilotettiin pussissa uuninrakoon tai navettaan. Näin talo pilattiin. Siellä alkoi kummitella tai ihmiset ja karja alkoivat sairastaa ja kuolla.

Häiriöiden ja vahinkojen aiheuttaminen oli helppoa, mutta niiden korjaaminen paljon vaikeampaa. Vain mahtavat tietäjät pystyivät hallitsemaan kirkonväkeä ja karkottamaan sen pois niin, että se myös pysyi poissa. Tarinat paheksuvatkin erityisesti taitamattomia taikojia, sillä heiltä väki saattoi karata sivullisten päälle. Tarinat varoittavat, että taikojen yrittäjät päätyvät itse nostamansa väen kynsiin.

Myös suurilla tietäjillä oli vaihteleva maine. Samalla kun he olivat yhteisön palvelijoita ja järjestyksen palauttajia, heitä epäiltiin myös järjestyksen horjuttamisesta. Jos heillä kerran oli kyky manata väki takaisin kirkkomaalle, heillä oli ilman muuta myös kyky aiheuttaa sillä pahaa. Kristillisesti sävyttyneestä näkökulmasta tietäjät olivat noitia, joiden myötä paholainen sai valtaa yhteisössä. Uskomusperinne korostaa sosiaalisen järjestyksen merkitystä. Se kertoo maailmasta, jossa moraali pitää yllä myös fyysistä maailmanjärjestystä. Ihmisten arkitodellisuuden ulkopuolella oli vieras, näkymätön maailma. Vainajat, pirut ja muut mönkiäiset pysyivät siellä omalla puolellaan vain jos raja pidettiin vahvana. Tarinoiden kuvaamat yliluonnolliset häiriöt ovat sekä 


\section{Kaarina Koski: Kuolema elävien naapurina}

konkreettisia pelotteita että symboli kaikelle yhteisöä uhkaavalle epäjärjestykselle. Moraalittomuus ja yhteisöön sopimaton käytös antoivat epäjärjestykselle valtaa, ja juuri niiden liepeillä huhuttiin nähdyn ja kuullun kummia. Vainajia, piruja, kirkonväkeä, männinkäisiä, hittusia, manalaisia purskahtaa esiin siellä, missä kaikki ei ole niin kuin pitää.

Järjestynyt yhteisö suojelee jäseniään. Tarinoissa dramaattisimmat kohtaamiset vainajien kanssa tapahtuvat alueilla, jotka eivät ole yhteisön omassa hallinnassa. Epämääräiset olennot parveilevat asumattomilla seuduilla. Niitä oleilee hautausmailla ja kirkoissa, jotka ovat pyhinä paikkoina henkimaailman eivätkä arjen aluetta. Myös aika jakautuu ihmisten ja henkien osuuksiin. Henkien liikkuma-aikoja ovat yöt, jotka eivät ole ihmisten toimille kuuluvaa aikaa.

\section{MielikUVA, USKOTTAVUUS JA KÄYTTÖARVO}

Uskomusperinteen näkökulma ei ollut ainoa tapa hahmottaa maailmaa. Varhaismodernissa Suomessa paitsi kirkko, myös kansakoululaitos sekä monet aatteelliset ja sivistysjärjestöt tarjosivat toisenlaisia ajatusmaailmoja. Näiden rinnalla kansanuskon status oli 1900-luvulla jo varsin heikko. Osa säilytti sen vielä aktiivisesti ohjenuoranaan, kun taas toiset sortuivat sen mukaisiin tulkintamalleihin vain heikkoina hetkinään. Ihmisillä oli - ja on edelleen - kyky omaksua ja soveltaa toiminnassaan keskenään täysin ristiriitaisia näkemyksiä. Käytännön tilanteissa tulkintamalliksi otetaan kulloinkin se, joka sopii senhetkisiin tunnelmiin tai suunnitelmiin. Ajatus vainajista pelottaa yöllä kuljettaessa hautausmaan ohi, mutta ei päivällä keitettäessä puuroa.

Uskominen on painoarvon asettamista jollekin mielikuvalle. Se on mielikuvan kokemista merkitykselliseksi. Uskominen on myös päämäärähakuista. Kertoja, joka ei yleensä usko taikoihin, voi kertomuksessaan silti vihjata naapurinsa pilanneen maagisesti hänen onneaan. Kertomuksen kärkenä on silloin vastuun siirtäminen itseltä naapurille. Ken uskoo naapurista pahaa, voi uskoa hetken myös maagiseen pilaamiseen.

Uskomusperinne on kuin sanastoa, jota kukin muotoilee omaan käyttöönsä sopivaksi. Tosinakaan esitetyt kertomukset eivät kuvaa objektiivisesti maailmaa tai kertojien näkemystä siitä. Ne voivat pyrkiä viihdyttämään ja hämmästyttämään. Ne voivat esittää myös voimakkaasti värittyneitä ja puolueellisia tulkintoja kuvaamistaan tapahtumista. Monet teksteistä ovat syntyneet esiintyvän taiteilijan vapaudella. Tutkijan tehtävänä on ymmärtää kerronnan suhde todellisuuteen.

Kerrottaviksi valikoituu yleensä uutiskynnyksen ylittäviä, jollakin tavalla poikkeuksellisia ja hämmentäviä tapahtumia. Yliluonnolliset ilmiöt ovat otollisia kertomusaiheita, koska ne ovat odottamattomia ja pelottavia ja niihin voi myös liittää vihjailua kanssaihmisten tekemistä rikoksista. Samaakin uskomustarinaa voi yksi kertoja pitää täytenä totena, toinen kertoo sitä osoituksena naurettavasta harhaluulosta ja kolmas esittää sitä viihteenä. Aiheen yleisyys ei kerro uskosta vaan siitä, että se on herättänyt mielenkiintoa. 


\section{SisäLTÖ MUUTTUU, KERRONTA JATKUU}

Uskomusperinne on ollut toisaalta konkreettisten tapahtumien tulkintaa, toisaalta sanastoa ja kuvastoa abstraktienkin asenteiden ja arvojen ilmaisemiseen. Elävien ja kuolleiden välisen kahtiajaon myötä uskomustarinat käsittelivät kysymystä omasta ja vieraasta - tutusta ja uhkaavasta. Niillä on ilmaistu ennakkoluuloja vierautta kohtaan ja käsitelty todellisia ja kuviteltuja uhkia. Samalla määriteltiin oman yhteisön rajoja ja koko totutun maailmanjärjestyksen rajoja, joiden ulkopuolella velloivat tuonpuoleinen, kaaos ja moraalittomuus.

Meidänkin aikanamme tarinoiden avulla leviää mielikuvia turvallista arkeamme ympäröivistä uhkista. Näkyvissä rooleissa näissä tarinoissa ovat muun muassa sairaudet, rikolliset ja narkomaanit, maahanmuuttajat, kasvoton byrokratia ja tehotuotanto. Näidenkin tarinoiden uskottavuus perustuu yleensä jo aiemmin omaksuttuihin mielipiteisiin kyseisistä ilmiöistä, ja keskustelussa niiden arvo on usein niiden kyvyssä kuohuttaa mieliä.

1900-luvun aikana kyläyhteisöt hautausmaineen muuttuivat ja kuva maailmasta avartui. Perinteen voi sanoa katkenneen, jos tarkastellaan vain tarinoiden sisältöjä. Hämmentävien ja uhkaavien asioiden käsittely kertomusten avulla kuitenkin jatkuu. Ajat muuttuvat, sanasto muuttuu, mutta traditio jatkuu.

Koski, Kaarina 2011: Kuoleman voimat. Kirkonväkei suomalaisessa uskomusperinteessä. Suomalaisen Kirjallisuuden Seuran toimituksia 1313. Helsinki: Suomalaisen Kirjallisuuden Seura.

Filosofian tohtori Kaarina Koski toimii tutkijana Helsingin yliopistossa, filosofian, historian, kulttuurin ja taiteiden tutkimuksen laitoksessa, folkloristiikan oppiaineessa. 